thorax possibly because of two large cysts getting infected. The anomaly is often present in men on the left side (Claman \& Ehrenheft, 1960 ; Rubin et al., 1966) as in this patient. The aberrant vessel supplied only the sequestrated mass. Pryce (1946) reported that this vessel may supply only the sequestrated segment, the normally connected lung or this segment along with adjoining area of normal lung. The possible existence of an anomalous vessel must be kept in mind while operating on cystic lung, otherwise the division of a supposed stout adhesion may cause fatal haemorrhage (Douglas, 1948). The aetiology of this condition is one upon which few investigators agree. The various theories of origin are summarized by Boyd (1953) and Boyden (1958).

\section{References}

Borrie, J., Lichter, I. \& RodDA, R. (1963) Intralobar pulmonary sequestration. Brit. J. Surg. 50, 623.

BoYD, G. (1953) Intralobar pulmonary sequestration. Dis. Chest, 24, 162.
BOyden, E.A. (1958) Bronchogenic cysts and the theory of intralobar sequestration. New embryologic data. J. thorac. Surg. 35, 604.

Claman, M.A. \& Ehrenheft, J.L. (1960) Bronchopulmonary sequestration. J. thorac. cardiovasc. Surg. 39, 531.

Douglas, R. (1948) Anomalous pulmonary vessels. J. thorac. Surg. 17, 712.

Foster-CARTER, A.F. (1963). In: Chest Diseases (Ed. by K. M. A. Perry and T. M. Sellors), Vol. I. Butterworths, London.

JAmes, W.B. \& Cuthbert, R.J. (1967) Intralobar pulmonary sequestration. Postgrad. med. J. 43, 359.

PryCe, D.M. (1946) Lower accessory pulmonary artery with intralobar sequestration of lung: A report of seven cases. J. Path. Bact. 58, 457.

RanNiger, K. \& Valvassori, G.E. (1964) Angiographic diagnosis of intralobar pulmonary sequestration. Amer. $J$. Roentgenol. 92, 540.

Rubin, E.H., Rubin, M., Attai, L. \& Heimann, W.G. (1966) Intralobar pulmonary sequestration: Aortographic demonstration. Dis. Chest, 50, 561.

Sutton, D. \& SAmuel R.H. (1963) Thoracic aortography in intralobar sequestration. Clin. Radiol. 14, 317.

TURK, L.N. \& Lindskog, G.E. (1961) The importance of angiographic diagnosis in intralobar pulmonary sequestration. J. thorac cardiovasc. Surg. 41, 299.

\title{
Unusual method of diagnosis in a case of benign duodenocolic fistula
}

\author{
J. H. P. Cuddigan \\ B.A., M.B., B.Ch. \\ Medical Registrar
}

\author{
M. A. EDgar \\ M.A., M.B., B.Ch. \\ Senior Surgical House Officer
}

St Peter's Hospital, Chertsey, Surrey

FIRST described by Sanderson in 1863, benign duodenocolic fistula is relatively rare, and only thirty-one cases have been described subsequently.* The condition is usually diagnosed from barium studies of the duodenum or, more commonly, the colon. This paper describes a case in which the diagnosis was made as a result of attempted jejunal biopsy, having been missed by conventional radiographic methods. The literature has been reviewed and the possible causes of the disease are discussed.

\section{Case report}

A 65-year-old woman had attended her own doctor with a 6-week history of diarrhoea, occasional vomiting and weight loss. The symptoms

\footnotetext{
*Seven cases of duodenocolic fistula complicating gallbladder disease have been described but excluded from the present review as they were really cholecysto-duodenocolic fistula.
}

had originally been thought due to acute gastroenteritis and she had been treated at home with antibiotics. However, the symptoms recurred and persisted for 2 months and she was admitted for investigation.

She had suffered occasional epigastric discomfort for some years, relieved by antacids. For 3 years she had been treated for hypertension with reserpine and Ismelin-Navidrex $K$. She had had no pain during her present illness and described her motions as loose, but not pale, and free from blood or mucus.

On examination, she was not clinically dehydrated but appeared mildly anaemic. Recent weight loss was apparent ; the abdomen appeared slightly distended and bore a mid-line hysterectomy scar. Further physical examination was normal.

Investigations: $\mathrm{Hb} 76 \%(11 \cdot 1 \mathrm{~g} / 100 \mathrm{ml})$; normal white blood cells and platelets ; MCHC 33\% ; ESR $15 \mathrm{~mm} / \mathrm{hr}$, serum iron $50 \mu \mathrm{g} / 100 \mathrm{ml}$; 
serum $B_{12} 320 \mu \mathrm{g} / 100 \mathrm{ml}$; serum folate $10 \mu \mathrm{g} /$ $100 \mathrm{ml}$.

Xylose absorption: $17 \%$ excreted in $5 \mathrm{hr}$. Faecal fats $25 \% 8 \mathrm{~g}$ and $22 \% 1 \mathrm{~g}$ per $24 \mathrm{hr}$.

The following investigations were normal: blood urea, serum electrolytes, proteins, calcium, phosphorus, alkaline phosphatase, liver function tests, glucose tolerance test, FIGLU excretion, stool for occult bloods and culture, sigmoidoscopy, plain X-ray of chest and abdomen. Barium enema, barium meal and small bowel meal were reported as essentially normal.

Following these investigations jejunal biopsy was attempted with a Crosby capsule. However, having entered the duodenum, the capsule passed directly downwards into the pelvis and a lateral radiograph showed it to have travelled anteriorly to lie in the colon (Figs. 1 and 2). Biopsy showed normal colonic mucosa.

Operation: On 13 September 1966, Mr C. J. Anders performed a laparotomy. A fistula was found connecting the duodenum at the junction of the second and third parts to the ascending colon. The fistulous track measured $\frac{1}{4}$ in. dia- meter $\times \frac{1}{4}$ in. length. The adjointing duodenum and colon were normal on palpation, and apart from an enlarged calcified lymph node situated locally, no other abnormality was found. The fistula was excised, together with a small rim of bowel wall at each end, and three lymph nodes, including the calcified gland were removed. The defects in colon and duodenum were sutured transverely.

The patient made an excellent recovery, gaining weight and remaining symptom-free after 9 months.

Histology ( $\mathrm{Dr}$ C. F. Ross): 'There is submucous fibrosis in the colon and scarring of the duodenal muscle; no active duodenal ulcer is seen, but it seems likely that there has been one which is now healed. The lymph node shows an eccentric mass of calcified fibrous tissuepresumably post inflammatory. There is nothing to suggest tuberculosis'.

\section{Discussion}

Aetiology: Duodenocolic fistulae reported to date have been attributed to various underlying

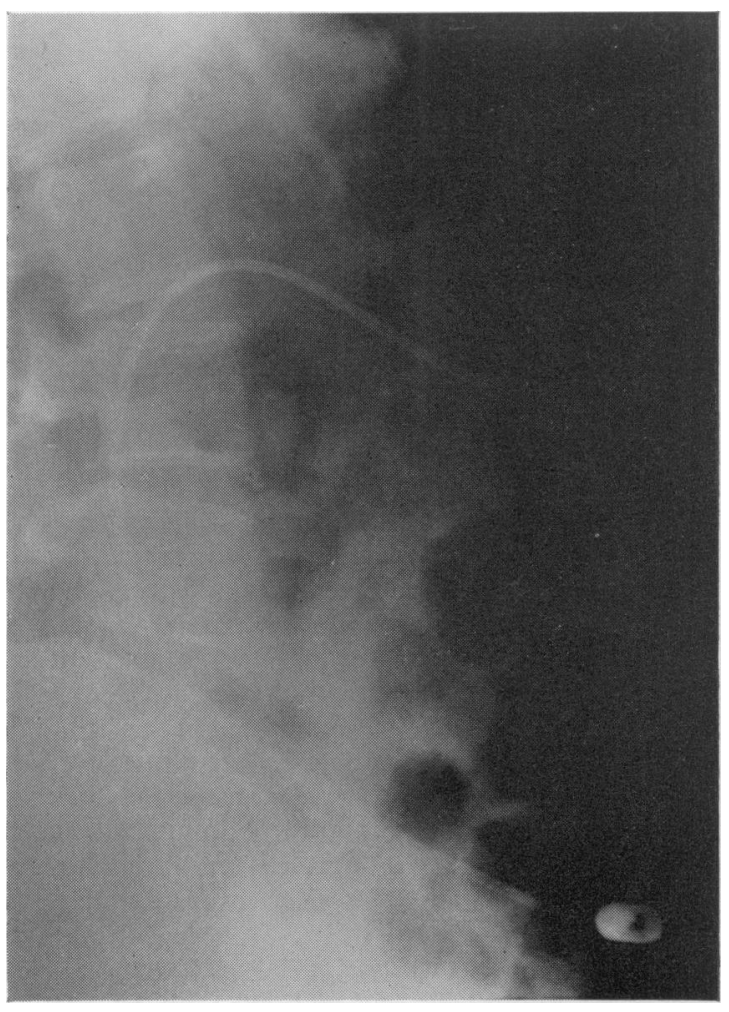

FIG. 1. 
TABLE 1

Classification of benign duodenocolic fistulae

\begin{tabular}{|c|c|c|}
\hline Aetiology & No. described & Reference \\
\hline Duodenal ulceration & $\begin{array}{l}11 \\
(2 \text { of these } \\
\text { doubtful) }\end{array}$ & $\begin{array}{l}\text { McPeak (1940), McClinton (1944), } \\
\text { Railton (1948), Rife (1951), } \\
\text { Olson (1951), Clayton \& Thornton (1953), } \\
\text { Nash \& Daland (1956), Pautler, Woodall \& Gaither (1958), } \\
\text { Grayson \& O'Connell (1960), Brindle \& Kane (1966) }\end{array}$ \\
\hline Tuberculosis & $\begin{array}{l}6 \\
\text { (only } 1 \text { of } \\
\text { these confirmed) }\end{array}$ & $\begin{array}{l}\text { Perry \& Shaw (1893), Ogilvie (1950), } \\
\text { Winfield (1951), Rosenquist \& Sjoberg (1955), } \\
\text { Brindle \& Kane (1966) }\end{array}$ \\
\hline Ulcerative colitis & 3 & $\begin{array}{l}\text { Ormandy \& Bargen (1939) } \\
\text { Ransome (1951) }\end{array}$ \\
\hline Regional enteritis & 3 & $\begin{array}{l}\text { Masters (1948) Grayson \& O'Connell (1960) } \\
\text { Hammersmith Conference (1961) }\end{array}$ \\
\hline Miscellaneous & 8 & \\
\hline Appendicitis & 2 & Clayton \& Thornton (1953), Marinaccio, Putignano \& Viterbo (1953) \\
\hline Duodenal diverticulum & 2 & Sanderson (1863), Winter (1959) \\
\hline Typhoid & 1 & Rees (1933) \\
\hline Trauma & 1 & Bucaille (1952) \\
\hline Cholecystitis & 1 & Rosenquist \& Sjoberg (1955) \\
\hline Unknown & 1 & Michell (1959) \\
\hline
\end{tabular}

pathologies (Table 1). The possibilities to be considered here include duodenal ulceration, tuberculosis, swallowed foreign body and previous drug therapy.

In this patient, a peptic ulcer perforating into the colon is the most likely cause. This is consistent with the histological findings and the past history of indigestion. She had also received treatment with reserpine and oral potassium, both of which have been incriminated in ulceration of the upper small intestine and these may be factors. However, the potassium the patient received was contained in a slow-release wax matrix and no cases of intestinal ulceration have been described with this preparation. The sex of the patient and site of the fistula are against a peptic aetiology; but such cases have been described (Olson, 1951, Brindle \& Kane, 1966), and a chronic duodenal ulcer in the second part of the duodenum is likely to perforate into the colon by reason of anatomical relations.

The only feature to suggest tuberculosis is the calcified lymph node. However, histology does not confirm this; calcification may be the endresult of any chronic inflammation. In several previous cases (Table 1) a diagnosis of perforating tuberculous ulcer has been suggested mainly on the basis of local calcified glands, none of which were examined histologically. In cases in which calcified glands have been examined histologically, no evidence of tubercle has been shown.

Rosenquist \& Sjoberg (1955) suggested that a sharp foreign body (e.g. fishbone) might be a cause in cases where the fistula was situated on the curve of the duodenum at the junction of the second and third parts. A local calcified lymph node, in their case, contained a giant cell of the foreign body type. In view of the identical site of the fistula, in the present case, a swallowed foreign body cannot be excluded.

Physiopathology. All cases previously described have been characterized by weight loss and most by diarrhoea. Two theories have been advanced to account for this:

(a) Passage of the duodenal contents into the colon with bypass of the small bowel.

(b) Retrograde passage of the colonic contents causing duodenitis and jejunitis.

Most evidence supports the latter theory. Lowden (1953) found in his series of gastro-jejunocolic fistulae, which had similar clinical presentations, that proximal defunctioning colostomy relieved the symptoms. In our patient, the symptoms were temporarily relieved by antibiotic treatment prior to hospital admission, the local changes in bowel flora obviously contributing to the malabsorption.

We also noted that the xylose absorption test 
was abnormal for a period postoperatively suggesting a recovering jejunitis.

Further support for the reflux theory is given by Laws \& Pitman (1960) who state that the intraluminal pressure of the colon is higher than that of the duodenum. However, with pressure variations due to bowel activity, passage of intestinal contents through the fistula will occur in both directions. At first the more fluid duodenal contents will pass into the colon; once a local colitis has been set up, leakage will occur in both directions and the resulting intestinal hurry will not only encourage further reflux but also lead to malabsorption.

Diagnosis: The diagnosis in this instance was established by the passage of the Crosby capsule through the fistula (Figs. 1 and 2). The position of the capsule was suggested radiologically and confirmed by colonic biopsy. That this was a remarkable occurrence was realized when the size of the fistula and the capsule were compared.

We would not suggest that this should be a routine method of attempting to prove a fistula, but feel that it should be given some prominence in this report. Approximately $90 \%$ of the reported cases have been diagnosed by barium enema, and the remainder by laparotomy or autopsy. Barium meal demonstrates a fistula less frequently than an enema.

Treatment: Nearly all cases have made an excellent response to corrective surgery. One patient died as a result of post-operative complication. Normal surgical routine of pre-operative replacement therapy and bowel sterilization is indicated. If a peptic aetiology is considered likely, vagotomy and pyloroplasty or gastroenterostomy may be advisable.

\section{Acknowledgments}

We should like to thank Dr O. R. L. Plunkett and Mr C. J. Anders for their kind permission to publish the case report, and to Dr C. F. Ross for the pathological report. We are grateful to Dr N. W. Grieve for his helpful criticism and advice.

\section{References}

BRINDle, M.J. \& KANE, J.F. (1966) Benign duodenocolic fistula. Brit. J. Surg. 53, 749.

BuCAILle, M. (1952) cited by Starzl et al. (1959).

Clayton, R.S. \& ThoRnton, W.L. (1953) Benign duodenocolic fistula. Radiology, 60, 832.

Grayson, M.J. \& O'Connell, M.D. (1960) Benign duodenocolic fistulae. Postgrad. med J. 36, 549.

Hammersmith Conference (1961) A case of Crohn's disease. Brit. med. J. i, 127.

Laws, J.W. \& Pitman, R.G. (1960) The radiological investigation of malabsorption syndromes. Brit. J. Radiol. 33, 211.

LowDEN, A.G.R. (1953) Gastrojejunocolic fistula. Brit. J. Surg. 41, 113.

Marinaccio, G., Putignano, T. \& Viterbo, F. (1953) cited by Starzl et al. (1959).

MASTERS, H. (1948) Duodenocolic fistula as a complication of regional ileitis. J. Mt Sinai Hosp. 15, 264.

McClinton, J.B. (1944) Non-malignant duodenocolic fistula. Canad. med. Ass. J. 51, 264.

McPeaK, C.M. (1940) Benign duodenocolic fistula with report of two cases. Radiology, 34, 343.

Michell, R.C. (1959) Delayed post-operative duodenocolic fistula. Brit. J. Radiol. 32, 55.

NASH, H.E. \& DALAND, E.M. (1956) Benign duodenocolic fistula. New Engl. J. Med. 254, 1032.

OgILvie, H. (1950) Non-malignant duodenocolic fistula, report of two cases. Ann. Surg. 131, 899.

OLson, J.D. (1951) Unusual gastro-intestinal fistulae. Amer. Surg. 17, 335.

Ormandy, L. \& Bargen, J.A. (1939) Thrombo-ulcerative colitis associated with cologastric and coloduodenal fistulae. Proc. Staff Meet. Mayo Clin. 14, 550.

Pautler, E.E., Woodall, J.C. \& Gaither, J.G. (1958) Benign duodenocolic fistula. Report of autopsy case due to peptic ulcer and review of literature. Arch. intern. Med. 102, 207.

Perry, E.C. \& Shaw, L.E. (1893) On diseases of the duodenum. Guy's Hosp. Rep. 50, 171

Rallton, S.V. (1948) Benign duodenocolic fistula. Canad. med. Ass. J. 59, 267.

RANSOME, H.K. (1951) cited by Rife (1951).

REES, C.E. (1933) Duodenocolic fistula with incompetent sphincter of Oddi. J. Amer. med. Ass. 100, 496.

RIFE, C.S. (1951) Benign duodenocolic fistula. Arch. Surg. (Chic.), 62, 876.

Rosenquist, H. \& SJoberg, S.G. (1955) Duodenocolic fistulae. Acta chir. scand. 109, 293.

SANDERSON, J.B. (1863) Duodenocolic fistula. Trans. Path. Soc. Lond. 14, 173.

Starzl, T.E., DorR, T.W. \& Meyer, W.H. (1959) Benign duodenocolic fistula. Arch. Surg. (Chic.), 78, 611.

WINFIELD, J.M. (1951) cited by Rife (1951).

WINTER, J. (1959) Benign duodenocolic fistula. J. Fac. Radiol. 10, 221. 